\title{
Perceptions of Using Private Dwellings at Gamaleyah as Airbnb Rent Listings in Old Historic Cairo
}

\begin{abstract}
By Mohamed Hany B. Moussa ${ }^{*}$, Mohamed Tawfeek Essawy ${ }^{ \pm}$, Fabio Naselli ${ }^{\ddagger}$ \& Islam Momtaz Mohamed ${ }^{+}$

The social movement renowned as the "sharing economy" is becoming increasingly noticeable in online peer-to-peer platforms recently. One of these platforms is Airbnb; an accommodation marketplace that offers access to alternative accommodation. These platforms have a mega important socioeconomic impact on tourist destinations. Old Cairo historic area encounters a lot of historical, heritage, and cultural features and folklores. Many owners of private homes in the area use them to accommodate guests and visitors to the area. Unfortunately, this is taking place under no organization or control by the Ministry of Tourism (MoT) since Egyptian accommodation regulations do not include a classification for such rent places. However, the area is well known among tourists and visitors and is included in downtown tours organized by tour operators and guides. This paper discusses the idea of using these homes as rent listings using the Airbnb platform among the executives of Historical Cairo Development Project (HCDP), Ministry of Tourism (MoT), and Egyptian Tourism Federation (ETF) as well as academics heading Heritage programs in Egyptian, Bahrain, and British Universities. This paper is devoted to revealing the differences in these perceptions among guests, professional practitioners, and academics, and officials "executives" of the government. Results indicate that all parties are in line with the idea and they recommended a change of regulations for that purpose.
\end{abstract}

Keywords: Airbnb platform, old Cairo, hospitality regulations, architectural heritage, local community welfare, functioning model

\section{Introduction}

The sharing economy has become a major phenomenon; Airbnb, Uber, ZipCar, Kickstarter, and many more embrace the speedily growing pioneers list in the world of sharing economy. This new concept has introduced an alternative peer-to-peer marketplace platform for consumers (Botsman and Rogers 2010, Botsman 2010).

The "P2P" or "Peer to Peer" business model is highly correlated to the sharing economy. This allows for the shared creation, production, distribution, and

\footnotetext{
*Professor, Hospitality Department, Faculty of Tourism and Hotel Management, Helwan University, Egypt.

${ }^{ \pm}$Researcher, Hospitality Department, Faculty of Tourism and Hotel Management, Helwan University, Egypt.

${ }^{\ddagger}$ Associate Professor, Architecture Department, Faculty of Architecture and Engineering, Epoka University, Albania.

${ }^{+}$Researcher, Ministry of Civil Aviation, Egypt.
} 
consumption of products and services among individuals (Tussyadiah 2015). To state it differently, the sharing economy joins individuals who have surplus property capacity to guests who require accommodation using an online platform maintained by a third-party company (Botsman and Rogers 2010). Together with the rise of the sharing economy, sharing private space takes place through platforms like Airbnb (Guttentag 2015), which became phenomenal. Airbnb, founded in 2008 , is a sharing economy platform for the short-term exchange of rooms and apartments for a fee (Airbnb 2017) despite that Airbnb operates in most locations with minimal regulatory controls (Ert et al. 2016). This paper aims to investigate the adequacy of Old Cairo historic area private homes for use as Airbnb listings for rent. The objectives were to detect variances among beneficiaries.

\section{Airbnb Guests' Perspectives}

A recent study explored sources of distrust in Airbnb. The study focused on Airbnb customers' negative reviews posted on Trustpilot's website (Sthapit and Björk 2019). The keyword on this search was based on the word "trust". Two thousand seven hundred and thirty-three comments were reviewed of which only two hundred and sixteen described distrust. These reviews constituted the sample of the research. Two main findings were found, poor customer service and host unpleasant behavior. Eventually, the study called for more care on service and a higher trust-based relationship between host and guests.

In recent years, the sharing economy has become rapidly permeating the lodging industry (Sthapit and Jiménez-Barreto 2018). "Share economy" is an umbrella term that covers the sharing of consumption through online platforms (Hamari et al. 2016). Airbnb is the world's largest accommodations provider in the shared economy (Mody et al. 2019). On the supply side, Airbnb enables private owners or tenants of houses, apartments, and spare rooms to offer their premises to visitors for short-term rentals (Sigala 2017). On-demand side, Airbnb fulfills travelers' needs, such as accommodations with lower prices and opportunities to interact with the local community (Guttentag 2015).

Many pieces of research examined Airbnb brand personality (Lee and Kim 2018), consumer experience (Pappas 2019), value co-destruction memorability, and sharing in the Airbnb context (Sthapit and Jiménez-Barreto 2018).

Customers of the sharing economy-like, Airbnb - are exposed to other risks than monetary loss (Ert et al. 2016), and guests may be confronted with unreliable hosts or even personal security (Huurne et al. 2017). In most cases, the host rents rooms to strangers (Ert et al. 2016), and the host competence defines the accommodation service quality (Zhang et al. 2018). As a result, many unexpected incidents may occur, as guests cannot determine one another's reliability in advance (Sun et al. 2019). For instance, a recent unfortunate incident involved the sexual assault of a nineteen-year-old boy by his Airbnb host during his stay in Madrid (Lieber et al. 2015). Although the notion of sharing assumes trust between the two parties, host and guest (Schor et al. 2015, Parigi and Cook 2015), such unpleasant experiences may certainly occur, and eventually causes distrust, and might discourage travelers from staying at Airbnb accommodations (So et al. 
2018). Recent studies identified distrust as one of the major barriers encountered in consumers' use of Airbnb (Tussyadiah and Pesonen 2018) and, in some cases, the only constraint that significantly predicts the overall consumer attitude towards Airbnb (So et al. 2018).

The core of a successful transaction in the sharing economy is the trust between providers and consumers in the sharing economy (Guttentag 2015, Zervas et al. 2015a, Ert et al. 2016). Negative experiences are possible even though it is generally presumed that experiences are positive encounters (Sthapit 2013). Despite some studies indicate that Airbnb possesses remarkable customer satisfaction levels, which is also evidenced by its user reviews (Ert et al. 2016), in the same vein, some recent studies identified an extremely positive bias among Airbnb's ratings (Zervas et al. 2015a, Bridges and Vásquez 2018).

Aside from monetary risks, additional risks do also exist in sharing economy platforms like Airbnb (Ert et al. 2016). The authors stress that "the mere act of sharing a home with a stranger can be risky". Such risks and unpleasant experiences may lead to distrust and discourage travelers from choosing Airbnb as an alternative to conventional accommodation types (So et al. 2018). From another perspective, since Airbnb is a third-party platform that offers online accommodation services between sellers and buyers, the risk is always there. However, Airbnb consumers have one choice but to estimate the risk of their transactions from the available information and communications because they cannot experience the actual service before they arrive at their chosen properties (Liang et al. 2018).

In the same context, most "P2P" accommodation platforms are suffering flimsy trust (Ert et al. 2016, Wu et al. 2017). Recent studies indicate that distrust is the most frequently cited barrier to "P2P" accommodation in a sharing economy, which includes the basic mistrust among strangers and privacy concerns (So et al. 2018, Tussyadiah and Pesonen, 2018).

\section{The Role of Heritage Branding in the Sharing Economy}

Recently, a series of new concepts that relate to new consumption and economic organizations forms have gained substantial importance, some of these concepts are shared consumption, collaborative economy, and sharing economy. The latter is based on the interaction between two or more parties using a digital platform (Botsman 2010). This reduces transaction costs. Airbnb is a case among those who offer and those who buy accommodation. Schor and Fitzmaurice (2015) also pointed out that consumers in the sharing economy tend to be of high cultural level people, which is a prevailing characteristic in urban destinations.

In traditional online platforms, consumer reviews or rating scores are key factors with which to build and enhance trust between consumers and sellers. However, in sharing economy platforms, such as Airbnb, host ratings are particularly high and positive (Hu et al. 2009, Zervas et al. 2015b). Some researchers found that hosts' photos on Airbnb may affect guests' decisions more than other attributes (Ert et al. 2016). Furthermore, in 21st-century cities, there are numerous attractions distributed throughout the city, enabling hosts to have unique and greater opportunities to market their offer. Thus, the sharing economy is 
embracing culture and heritage to exhibit and promote its authenticity, a key factor when generating the trust and the satisfaction of guests (Kolar 2010, Lalicic and Weismayer 2017).

Considering all the above, this new socio-economic movement- which includes the concepts mentioned above- gained additional momentum, due to the interval of several emerging social, cultural, and economic situations. In social media, users are no longer passive beings seeking and receiving information; instead, the logic of connectivity between peers - or "P2P" - facilitates direct contact between users, without the need for intermediation. The rules of the game have changed, and social media has promoted the empowerment of consumers.

According to the Spanish National Commission on Markets and Competition (NOU 2017), the sharing economy is a novel economic model, based on the exchange of goods and services and rented assets, these assets are provided in exchange for some sort of benefit agreed upon between the parties. The change that is occurring, regarding the consumption habits of people, is exceptional. This was translated into substantial growth in shared digital economy platformsusually a digital framework - that only a few years ago reported residual activity. Redefining tourism, Zervas et al. (2017) see a series of conclusions to draw. That there was a significant negative impact on hotels and that this impact was not heterogeneous. The most affected were the modest and standard establishments, whereas luxury establishments did not report significant alterations. Due to this impact, it was noticeable that hotels had taken competitive measures, such as lowering prices.

In the case of Bilbao, however, it was found that the Airbnb platform had no detrimental effects on the operation of traditional hotels, due to the relatively small weight it still has in Bilbao (Fierro and Salmón 2017).

The main conclusion here is that the hosts creating image branding cause a positive impact on the sharing economy and tourism. In this way, the hosts become co-initiators of the city branding, this is the crossover point between heritage tourism and the sharing economy. Moreover, the events that take place in the city could also be included as heritage elements.

Finally, it would be interesting to analyze the reasons why the hosts rent out their own homes, and whether it is a response to the need for living or is a pure business motivation. Moreover, if there is voluntary gentrification for heritage sites and surroundings it is believed that it is thanks to Airbnb (Chen and Rothschild 2010).

\section{Integration of Tourism Sustainability and Airbnb}

Tourism integration surpasses the outmoded concept of offers. It is benefitting the interpersonal connections and environmental ones and stimulating the historical/cultural sensibility in the dialog between bidders and receivers. This is done through the integration between the productive areas of the micro and middle sizes, with the aid of technologies, pursues, and encourages tenable development. The term "Integrated" indicates the objective of support. In integrated relational tourism, not only the cultural activity become elements characterizing of territory 
but also the local productions (agricultural and handicraft), become the same and, at the same time, fundamental levers of marketing on that work strategically to prime and to maintain the virtuous circles that subtend the development. Human interaction and communication return to be central in every phase of the trial. This is the meeting among people places, culture, values, and tourism (Cardaci et al. n.d.).

The perspectives of relational tourism- as alternative tourism- are those that maintain within the territory the greater quantity of the tourist surplus. The relational tourism is, in fact, "integrated" with the activity and the resources of the territory productive-handicraft and historian-cultural. The good part is that the hospitality offered here is one of the same typology of rural tourism (villages, beams, farms, villas, etc.) calling in also some cause parts historical of the town, of the villages and the countries, stretching the offer of assets and services to all the environment, urbanized and not, to its products, to its story, and its culture (ChicaOlmo et al. 2017). This includes direct management, the alive offer in the places, develops traditional activity, and root incomes in the territory. Besides, this integrated type builds themselves widespread relations via the use of the technology of data transmission where the host is directly reached at home (faceto-face) from the ones which offer the hospitality like Airbnb. Five typologies of elementary sustainability are individualized from the studies on integrated tourism: Environmental Sustainability, Social Sustainability, Human Sustainability, and Economical Sustainability, besides financial, Technological Sustainability (Chen and Rothschild 2010).

\section{History of Old Cairo Historic Area}

Cairo has a complex history of domination that followed over the centuries, from 969 AC, when Gwadar traces the path of a quadrangular which were then built and made the walls of Cairo, until the arrival -in 1798- of Napoleon's troops. The first is the urban core Fustat, a word of Greek origin that means in Egyptian camp surrounded by a moat, and dates back to the military camp Caliphs in 640 $\mathrm{AD}$, used to lay siege to the ancient fortress of Babylon, Egypt, built by the Romans the place where the slaves deported from Babylon, had allocated. The fortress was a settlement and its conquest meant for Arabs the opportunity to create a strategic base for expansion throughout North Africa (Swelim 2015). 
Figure 1. Old Historic Cairo Map

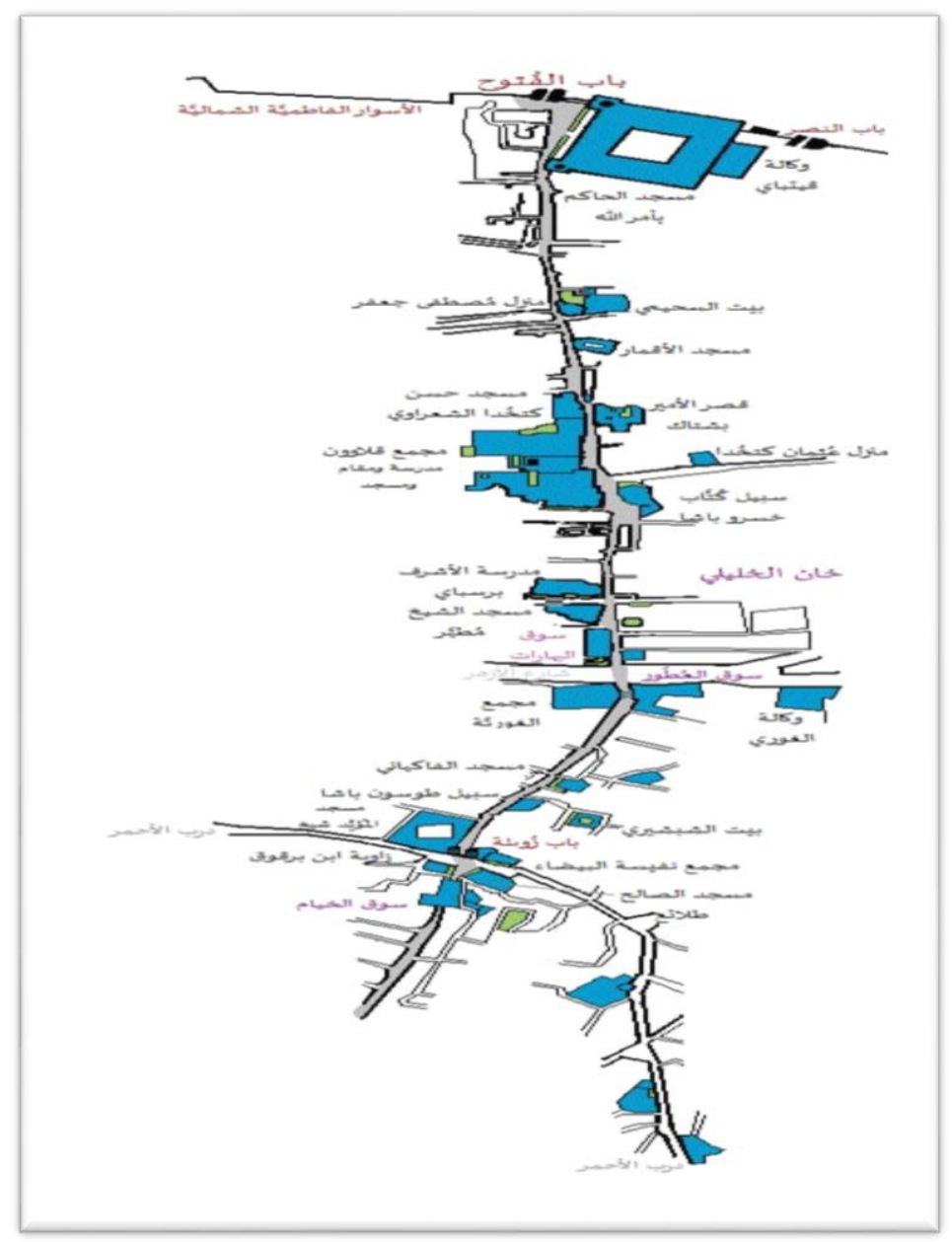

The form of the camp set up was very similar to the Roman era and was ruled by general "Amr ibn al-" as which has built-in 642 A.D., the mosque named the first Muslim place of worship on the territory of Africa. Around the mosque, as in the traditional conception of the matrix territory, expanded the settlements, which was divided into sectors, "Khitta", in which it settled about fifty tribes, reflecting social organization that was available from the center, consisting of the mosque, to the sides in a rigid schedule. The mosque of Amr had fourfold importance because it did not represent only the center of worship but also performed duties of defense, justice, and social aggregation. The new settlement had incorporated the remains of Babylon, which was inhabited by the Coptic elite of officials and was preparing to become, for many centuries, joined later by the al-Qahira, the most important report and trade across the region. At the Omayyad Dynasty (661-750) followed that of Abbasids who, after having besieged Fustat, entered the north of the site, providing it with a new mosque, a palace headquarters of the government, and a market. This site took the name of Al-Askar and his move away from the previous wording was not grounds for expansion of the city but met a phenomenon typical of the history of the Muslim world, called "dynastic urbanism". This attitude was confirmed in the subsequent reign of Ibn Tulun (868 AD), the most 
famous Abbasid governor, which used the premises earlier, but used a place already occupied by the graves of a Jew and a Christian cemetery in a strategic position at the foot of the hills Muqattam (Fletcher-Jones 2016).

Again, the territory was divided into lots and the mosque was built by Ibn Tulun became the center of social life. The name of the new site was al-Qata'i and inside, over the mosque, built a new royal palace, a major commercial avenue that linked these new places.

\section{Regulations of Classifications for Hospitality Operations in Egypt}

The Ministry of Tourism is the Egyptian governmental entity responsible for licensing of hospitality operations. The licensing is done based on ministerial decree number 26 (1,2 and4) issued in 1982. This decree had been in use till 2006. One update was done in 2006 keeping the same criteria intact also keeping the same classifications intact. According to this classification Egyptian hotels fall under one of the following categories

One to five-star hotels, One to five-star Holiday Villages, One to Five-star Floating hotels, Tourist apartments, and unclassified enterprises (ETF 2018).

In November 2018, Egypt launched the Egypt-Tourism Reform Program (E-TRP) with a vision to achieve a sustainable tourism sector through implementing structural reforms that strengthen the sector's competitiveness and are consistent with international standards (Egypt Today 2019).

Updating the hotel classification criteria according to international standards is a major cornerstone, according to Mashat (2018) who stated that "Today, and in collaboration with the UNWTO and Egypt's Hotel Association, this important cornerstone has been completed".

For the first time, new types of hotels, namely, Eco- friendly Lodges, Dahabeya, Heritage Hotels, Apartment Hotels, and Environmental Safari Camps were included in the New Hospitality Criteria, according to a statement issued by the Tourism Ministry. This decision was made considering the increasing international demand for such hotels.

This is an important step that will give the Ministry of Tourism the leverage to monitor them and ensure the quality of services provided to Egypt's tourists are in line with international standards. However, single private rooms and suites within private homes were included neither in old nor in new classification guides (Egypt Today 2019).

\section{Methodology}

A cross-sectional study was conducted during the period from July 2019 to April 2020 using an online questionnaire via Survey Monkey site on the Google platform. The survey was forwarded to guests who previously visited or stayed in the Old Cairo historic area or its surroundings.

The research has utilized two methodological tools to obtain the data required. These tools are guest questionnaires and in-depth interviews. 
The questionnaire research tool was a semi-structured questionnaire developed for this study. It included 10 choice questions besides one open-ended question for comments. These questions meant to measure support given by MoT, perception of this proposed type of business, the adequacy of architectural and cultural features to encourage the proposed idea, the already existing business in the area, support of other governmental bodies, the fit of the area urban design for the proposed idea, regulations needed, cultural exchange possibility among inhabitants and visitors, and the probable positive impact of the idea on the welfare of the area inhabitants in the same sequence they are mentioned. The open-ended question was used for respondents to voice their comments.

A five-point Likert scale was used in the choice questions ranging between 1 (strongly disagree) to 5 (strongly agree). The mean score was calculated for each item to yield a range from 0 to 5. Subsequently, Likert grades were applied like follows: Grade 1(1-1.80), Grade 2 (1.81-2.60), Grade 3 (2.61-3.40), Grade 4 (3.41-4.20), and Grade 5 (4.21-5).

The questionnaire was circulated among repeated guests and visitors of the area using the Survey Monkey tool on the Google platform and 356 questionnaires were obtained valid for analysis.

Besides, 10 in-depth interviews were conducted using the same tool with high-rank officials representing governmental entities as well as top-rank academics. Entities investigated included:

- Heritage Department of Cairo Governorate

- Ministry of Tourism

- Egyptian Tourism Federation

- Historic Cairo Development Project

- Heritage Conservation and Site Management Program, Helwan University, Egypt

- Heritage Conservation Program, Bahrain University, and Heritage Conservation and Site

- Management Program LSBU, UK

\section{Reliability Analysis}

For the survey statements, the Cronbach Alpha coefficient was calculated to decide on the internal consistency of the survey. The computation of Alpha Chronbach was 0.882 . The reliability coefficient equal to or higher than 0.70 is considered acceptable in social science researches generally (Pallant 2007). Therefore, the instrument proved to be reliable.

\section{Statistical Packages Used}

The statistical package for social science SPSS Version 20 for Windows and Excel statistical package Version 19 for Windows were used to analyze data collected. A descriptive analysis was used to present data. Alpha Cronbach, 
frequency, percentile, mean, standard deviation, t-test, Chi-square, correlation coefficient, and Anova test were used.

\section{Results and Discussion}

Table 1 discloses many findings of guests' viewpoints. First, that guests believe Airbnb needs to be supported by MoT. This question gained the first ranking of importance as expressed by respondents. Guests who previously visited the area had experience there and probably felt the area needs more attention, conservation, and maintenance and therefore, believe this is the responsibility of the Egyptian government represented in MoT.

Second, respondents expressed that the urban design of the Old Cairo historic area and its heritage surrounding areas fit for accommodating tourism and tourists. Many guests around the world now prefer to stay in historical and heritage areas and prefer to stay around these areas. This calls for MoT to stimulate and encourage the use of private homes in Airbnb activities in the Old Cairo historic area. The two findings somehow correlate with each other.

Table 1. Ranking of Statements according to their Importance as Perceived by Guest Respondents

\begin{tabular}{|c|c|c|c|}
\hline Questions & Frequency & $\begin{array}{c}\text { W. } \\
\text { Average }\end{array}$ & Ranking \\
\hline \multirow{5}{*}{$\begin{array}{l}\text { Q1: MoT supports the use of private dwellings in } \\
\text { Airbnb }\end{array}$} & 74 & 370 & \\
\hline & 114 & 456 & \\
\hline & 54 & 162 & \\
\hline & 54 & 108 & \\
\hline & 60 & 60 & \\
\hline & & 1156 & 1 \\
\hline \multirow{5}{*}{$\begin{array}{l}\text { Q2: Airbnb can attract lots of lucrative business to } \\
\text { Egypt }\end{array}$} & 74 & 296 & \\
\hline & 182 & 546 & \\
\hline & 67 & 134 & \\
\hline & 20 & 20 & \\
\hline & 13 & 65 & \\
\hline & & 1061 & 4 \\
\hline \multirow{5}{*}{ Q3: Architectural \& cultural features support Airbnb } & 80 & 320 & \\
\hline & 175 & 525 & \\
\hline & 94 & 188 & \\
\hline & 0 & 0 & \\
\hline & 7 & 35 & \\
\hline & & 1068 & 3 \\
\hline \multirow{6}{*}{$\begin{array}{l}\text { Q4: There is already business in the area from tour } \\
\text { operators and guides }\end{array}$} & 108 & 324 & \\
\hline & 114 & 228 & \\
\hline & 80 & 80 & \\
\hline & 14 & 70 & \\
\hline & 40 & 160 & \\
\hline & & 862 & 8 \\
\hline
\end{tabular}




\begin{tabular}{|c|c|c|c|}
\hline \multirow{5}{*}{$\begin{array}{l}\text { Q5: Concerned governmental bodies support the use of } \\
\text { private dwellings in Airbnb }\end{array}$} & 88 & 264 & \\
\hline & 88 & 264 & \\
\hline & 114 & 228 & \\
\hline & 33 & 33 & \\
\hline & 33 & 165 & \\
\hline & & 954 & 7 \\
\hline \multirow{6}{*}{$\begin{array}{l}\text { Q6: Old Cairo Historic area is already included in } \\
\text { downtown tours }\end{array}$} & 100 & 300 & \\
\hline & 88 & 176 & \\
\hline & 74 & 74 & \\
\hline & 54 & 270 & \\
\hline & 40 & 160 & \\
\hline & & 980 & 6 \\
\hline \multirow{6}{*}{$\begin{array}{l}\text { Q7: The urban design of Old Historic Cairo fits for } \\
\text { accommodating tourism }\end{array}$} & 80 & 320 & \\
\hline & 175 & 525 & \\
\hline & 88 & 176 & \\
\hline & 0 & 0 & \\
\hline & 14 & 70 & \\
\hline & & 1091 & 2 \\
\hline \multirow{6}{*}{$\begin{array}{l}\text { Q8: Legislations need to be modified to allow the use of } \\
\text { Airbnb }\end{array}$} & 88 & 264 & \\
\hline & 166 & 332 & \\
\hline & 74 & 74 & \\
\hline & 14 & 70 & \\
\hline & 14 & 56 & \\
\hline & & 796 & 10 \\
\hline \multirow{6}{*}{$\begin{array}{l}\text { Q9: The application of Airbnb in Old Historic Cairo } \\
\text { encourages cultural exchange }\end{array}$} & 94 & 376 & \\
\hline & 121 & 363 & \\
\hline & 114 & 228 & \\
\hline & 20 & 20 & \\
\hline & 7 & 35 & \\
\hline & & 1022 & 5 \\
\hline \multirow{6}{*}{$\begin{array}{l}\text { Q10: Airbnb can contribute positively to the socio- } \\
\text { economic community welfare }\end{array}$} & 135 & 405 & \\
\hline & 154 & 308 & \\
\hline & 53 & 53 & \\
\hline & 7 & 35 & \\
\hline & 7 & 28 & \\
\hline & & 829 & 9 \\
\hline
\end{tabular}

Third, respondents expressed their belief that the architectural and cultural features of the Old Cairo historic area and its surrounding locality gives support to the use of private homes at Old Cairo historic area as accommodation facilities for Airbnb. This goes in the same vein as the two previous questions. That those, guests believe that the architectural and cultural features of the Old Cairo historic area and its surrounding localities pave the way towards the use of already existing private homes in the same area as accommodation facilities for Airbnb guests and that MoT should give support to this. This coincides with one of the main requirements of Airbnb activities.

From an economic perspective respondents when asked about whether Airbnb can attract lucrative business to the area designated, respondents "guests 
previously visited the area" showed their belief that Airbnb activities in this area of Old Cairo historic area can attract lots of lucrative business to add to the Egyptian inbound tourism.

Fifth, within the same vein, respondents believed that the institution of Airbnb application at Old Cairo historic area can encourage the exchange of culture among residents from one side and guests from the other side. It is important to stress that respondents previously visited the area and mingled with the local culture there, even more, they accepted and probably enjoyed staying in that area and therefore support the exchange of their culture with those of residents, this came in the fifth ranking according to weight.

Sixth ranking according to weight however represented those respondents who assured that private homes at Old Cairo historic area suites the purpose of accommodation facilities for tourists via Airbnb application. Respondents are very enthusiastic about the area, its surrounding heritage, its culture and express their desire to be accommodated there.

Seventh, within the same context, respondents urged government entities to give support to the idea of using private homes as Airbnb rent listings in the Old Cairo historic area. This goes alongside with previous findings and gives evidence on the enthusiasm of guests for the area of Old Cairo historic area.

In the eighth weighted rank, respondents stated that tour operators and tour guides already include the area of Old Cairo historic area in their downtown tour itineraries. The late ranking here refers to the fact that those guests previously visited the area and that they sought no need to urge for that since it is already taking place.

The ninth rank shows respondents' interest in social contribution to the wellbeing of the residents and inhabitants of the area. However, since the ranking comes late in weight and grade, this means that the guest is not very keen on whether the introduction of the designated idea may or may not benefit residents. This finding is somehow puzzling.

The final tenth ranking by respondents was that of question number eleven, where respondents were asked about the need to modify legislations of MoT to permit the use of private homes at Old Cairo historic area and its surrounding localities as accommodation facilities within Airbnb activities.

Most probably this is due to a lack of knowledge from the part of respondents that such legislations do not exist. Or it might be due to the perception among respondents that these legislations are not required because most of them are foreigners. 
Table 2. Descriptive Analysis of Guests regarding the Use of Private Homes as Airbnb Rent Listings at Old Cairo Historic Area

\begin{tabular}{|c|c|c|c|c|c|c|c|c|c|}
\hline Questions & F \& \% & $\begin{array}{c}\text { S. } \\
\text { Disagree }\end{array}$ & Disagree & Neutral & Agree & $\begin{array}{c}\text { S. } \\
\text { Agree }\end{array}$ & Mean/ SD & $\begin{array}{l}\text { Likert } \\
\text { Grade }\end{array}$ & $\begin{array}{c}\mathbf{P} . \\
\text { Value }\end{array}$ \\
\hline \multirow[t]{2}{*}{ Q1 } & $\mathbf{F}$ & 60 & 54 & 54 & 114 & 74 & & & \\
\hline & $\%$ & 17 & 15.1 & 15.1 & 32.1 & 20.8 & $3.24 \pm 1.5$ & 3 & 0.26 \\
\hline \multirow[t]{2}{*}{ Q2 } & $\mathbf{F}$ & 13 & 20 & 67 & 182 & 74 & & & \\
\hline & $\%$ & 3.8 & 5.7 & 18.9 & 50.9 & 20.8 & $3.79 \pm 0.8$ & 4 & 0.57 \\
\hline \multirow[t]{2}{*}{ Q3 } & $\mathbf{F}$ & 7 & 0 & 94 & 175 & 80 & & & \\
\hline & $\%$ & 1.9 & o & 26.4 & 49.1 & 22.6 & $3.91 \pm 0.8$ & 4 & $0.038^{*}$ \\
\hline \multirow[t]{2}{*}{ Q4 } & $\mathbf{F}$ & 40 & 14 & 80 & 114 & 108 & & & \\
\hline & $\%$ & 11.3 & 3.8 & 22.6 & 32.1 & 30.2 & $3.65 \pm 1.3$ & 4 & 0.71 \\
\hline \multirow[t]{2}{*}{ Q5 } & $\mathbf{F}$ & 33 & 33 & 114 & 88 & 88 & & & \\
\hline & $\%$ & 9.4 & 9.4 & 32.1 & 24.5 & 24.5 & $3.44 \pm 1.12$ & 4 & $0.05^{*}$ \\
\hline \multirow[t]{2}{*}{ Q6 } & $\mathbf{F}$ & 40 & 54 & 74 & 88 & 101 & & & \\
\hline & $\%$ & 11.3 & 15.1 & 20.8 & 24.5 & 28.3 & $3.23 \pm 1.14$ & 4 & 0.15 \\
\hline \multirow[t]{2}{*}{ Q7 } & $\mathbf{F}$ & 14 & 0 & 88 & 175 & 80 & & & \\
\hline & $\%$ & 3.8 & 0 & 24.5 & 49.1 & 22.6 & $3.87 \pm 0.9$ & 4 & $0.014^{*}$ \\
\hline \multirow[t]{2}{*}{ Q8 } & $\mathbf{F}$ & 14 & 14 & 74 & 166 & 88 & & & \\
\hline & $\%$ & 3.8 & 3.8 & 20.8 & 47.2 & 24.5 & $3.85 \pm 0.9$ & 4 & 0.21 \\
\hline \multirow[t]{2}{*}{ Q9 } & $\mathbf{F}$ & 7 & 20 & 114 & 121 & 94 & & & \\
\hline & $\%$ & 1.9 & 5.7 & 32.1 & 34 & 26.4 & $3.77 \pm 0.9$ & 4 & 0.15 \\
\hline \multirow[t]{2}{*}{ Q10 } & $\mathbf{F}$ & 7 & 7 & 53 & 154 & 135 & & & \\
\hline & $\%$ & 1.9 & 1.9 & 15.1 & 43.4 & 37.7 & $4.13 \pm 0.8$ & 4 & 0.011* \\
\hline \multicolumn{2}{|c|}{ Weighted Mean } & & & & & & $3.71 \pm 0.58$ & & \\
\hline
\end{tabular}

Significant correlation at $\mathrm{P}<0.05$; SD standard deviation.

According to Table 2, the outcomes regarding perceiving the idea of using private homes as Airbnb rest listings at the Old Cairo historic area showed many interesting findings. The highest scores $(4.31 \pm 0.08)$ was for Q10 "Airbnb can contribute positively to social responsibility through creating an unlimited number of jobs and the welfare of inhabitants at Old Cairo historic area and its heritage surrounding sites", followed by Q3, "The architectural and cultural features, surroundings and locality support Airbnb activities at Old Cairo historic area" where scores were (3.91 \pm 0.8$)$. Followed by Q7, "The urban design of Old Cairo historic area and its heritage surrounding sites fit for accommodating tourism and tourists" scoring (3.87 \pm 0.9$)$. Adversely, the lowest score, surprisingly was that of Q1, "MoT supports the use of private homes for Airbnb activities" scoring $(3.24 \pm 1.5)$. This means that respondents are not aware or are not convinced that MoT is supporting the designated idea.

Most important is that using private homes available at Old Cairo historic area as accommodation listings in Airbnb was significantly correlated with, "The architectural and cultural features, surroundings and locality support Airbnb activities at Old Cairo historic area" $(p=0.038)$, "the urban design of Old Cairo historic area and its heritage surrounding sites fit for accommodating tourism and 
tourists" ( $p=0.014)$, "Concerned governmental bodies support the use of private homes in Airbnb activities" $(p=0.05)$ and, "Airbnb can contribute positively to social responsibility through creating an unlimited number of jobs and the welfare of inhabitants at Old Cairo historic area, and its heritage surrounding sites" $(p=0.011)$. This indicates the relevance of architectural and cultural features of Old Cairo historic area and its surrounding area, as well as its unique urban design, which can contribute positively to the welfare of its inhabitants and residents provided that this gets support from governmental bodies.

\section{Governmental Bodies’ Executives in-Depth Interview Analysis}

To complete the picture and have a full image of the situation concerning the use of private homes at the Old Cairo historic area and its surrounding localities it seemed necessary to have in-depth interviews to explore the viewpoints of representatives of governmental bodies involved in this application as well as academics involved in heritage preservation graduate and post-graduate studies introduced by Egyptian universities.

Ten In-depth interviews were conducted face to face with executives of the Egyptian Federation of Tourism and the MoT. Also, these interviews included executives of both the Heritage Department at Cairo Governorate (HDCG) and those of the Historic Cairo Development Project. The Chamber of travel agents (CTA), and the chamber of Hotel Facilities (CHF) were also represented in these in-depth interviews. Besides, academics involved in heritage educational graduate and post-graduate studies in Egypt, Bahrain, and Great Britain were also interviewed via mail and zoom meetings. Table 3 shows the responses of those academics and practitioners and executives.

Table 3. Ranking of Practitioners/Academics Responses

\begin{tabular}{|l|c|c|c|c|c|c|c|}
\hline Question & $\begin{array}{c}\text { Strongly } \\
\text { Disagree }\end{array}$ & Disagree & $\begin{array}{c}\text { Neither } \\
\text { Agree nor } \\
\text { Disagree }\end{array}$ & Agree & $\begin{array}{c}\text { Strongly } \\
\text { Agree }\end{array}$ & Weight & Ranking \\
\hline 1 & 1 & 3 & 2 & 3 & - & 25 & 9 \\
\hline 2 & - & 1 & 1 & 4 & 4 & 41 & 5 \\
\hline 3 & - & 1 & - & 5 & 4 & 42 & 4 \\
\hline 4 & - & 3 & 3 & 3 & 1 & 32 & 7 \\
\hline 5 & 1 & 3 & 4 & 1 & 1 & 28 & 8 \\
\hline 6 & - & 2 & 3 & 2 & 3 & 36 & 6 \\
\hline 7 & - & 2 & - & 2 & 6 & 42 & 4 \\
\hline 8 & - & - & 1 & 4 & 5 & 44 & 3 \\
\hline 9 & - & - & - & 5 & 5 & 45 & 2 \\
\hline 10 & - & - & - & 4 & 6 & 46 & 1 \\
\hline
\end{tabular}

To further explore the difference between the group of professional practitioners and academics t-test was employed. Table 4 shows the results of the test. 
Table 4. Difference between Practitioners and Academics

\begin{tabular}{|l|c|c|c|c|c|}
\hline X1 Prof. & Dif(X-M) & Sq.Diff(X-M)2 & X2. Acadm & Dif(X-M) & Sq.Diff(X-M)2 \\
\hline 17 & -3 & 9 & 13 & -5 & 25 \\
\hline 21 & 1 & 1 & 18 & 0 & 0 \\
\hline 22 & 2 & 4 & 23 & 5 & 25 \\
\hline 17 & -3 & 9 & 14 & -4 & 16 \\
\hline 15 & -5 & 25 & 13 & -5 & 25 \\
\hline 19 & -1 & 1 & 17 & -1 & 1 \\
\hline 21 & 1 & 1 & 15 & -3 & 9 \\
\hline 23 & 3 & 9 & 22 & 4 & 16 \\
\hline 23 & 3 & 9 & 22 & 4 & 16 \\
\hline 22 & 2 & 4 & 23 & 5 & 25 \\
\hline$M=20$ & ss.72 & & M=18 & ss. 158 & p-value 0.22692 \\
\hline
\end{tabular}

The $t$-value is 1.25109 . The $p$-value is 0.22692 . The result is not significant at $p<0.05$.

Since $t$ value $=1.25109, p$-value $=0.22692$ at a significance level of $<0.05$, therefore, it is possible to accept the null hypothesis and therefore, meaning there are no significant differences between professional practitioners and academics regarding their viewpoints towards the use of private homes as Airbnb units for rent at Old Cairo historic area. Moreover, the Person correlation value is $(0.8813)$ which means there is a high correlation between the academics and the practitioners concerning the aforementioned idea.

Academics had a lower mean $(M=18)$ than the practitioner's mean $(M=20)$. In a sense, this might be interpreted as more conservatism from the part of academics than their counterparts of professional practitioners towards the use of private homes as Airbnb listings in the Old Cairo historic area. Therefore, it can be concluded that practitioners including government executives support and encourage the idea of using private homes as listings on the Airbnb platform while academics are a bit conservative despite they also support the idea.

To further explore the perceptions of all parties concerned re-ranking of statements according to the importance and Anova analysis were conducted. These tests were meant to reveal the differences between practitioners, academics, and guests concerning the application of the investigated idea. Table 5 shows a reranking of the importance of statements from guests' viewpoints compared to practitioners and academics.

Table 5. Comparative Ranking of Guests to Practitioners and Academics

\begin{tabular}{|l|l|}
\hline Guests Ranking of Statements & Practitioners/academics Ranking \\
\hline 1. MoT supports the idea & 1. The idea contributes to comu. welfare \\
\hline 2. Urban design fits Airbnb listing & 2. Cultural features support the idea \\
\hline 3.Arch. Features support the idea & 3. Regulations need to be changed \\
\hline 4. The idea can drive lucrative business & $\begin{array}{l}\text { 4. Urban design fits Airbnb listing } \\
\text { 4. Arch. Features support the idea }\end{array}$ \\
\hline 5. Cultural features support the idea & 5. The idea can drive lucrative business \\
\hline 6. Business already exists in O.H Cairo & 6. T.leaders \&guides take guests there \\
\hline 7. Government bodies support the idea & 7. Business already exists in O.H Cairo \\
\hline 8. T.leaders \&guides take guests there & 8. Government bodies support the idea \\
\hline 9. The idea contributes to comu. welfare & 9. MoT supports the idea \\
\hline 10. Regulations need to be changed & ----------------------------------------- \\
\hline
\end{tabular}


Moreover, Anova tests were conducted to reveal differences among groups investigated. Table 6 displays Anova test results on comparing practitioners to guests.

Table 6. Anova Test Results - Comparison of Practitioners and Guests

\begin{tabular}{|l|c|c|c|}
\hline \multicolumn{4}{|c|}{ Summary of Practitioners and Guests Data } \\
\cline { 2 - 4 } & \multicolumn{2}{|c|}{ Treatments } & Total \\
\cline { 2 - 4 } & 1 & 2 & 20 \\
\hline $\mathrm{N}$ & 10 & 10 & 2163.8 \\
\hline $\mathrm{X}$ & 200 & 1963.8 & 108.19 \\
\hline$\sum \mathrm{X}^{2}$ & 20 & 196.38 & 394946.5 \\
\hline Std.Dev. & 4072 & 390874.5 & 92.0083 \\
\hline
\end{tabular}

\begin{tabular}{|l|c|c|c|c|}
\hline \multicolumn{5}{|c|}{ ANOVA of Practitioners and Guests Data } \\
\hline Source & SS & df & MS & \\
\hline Between-treatments & 155549.522 & 1 & 155549.5 & $F=528.73271$ \\
\hline Within-treatments & 5295.476 & 18 & 294.1931 & \\
\hline Total & 160844.998 & 19 & & \\
\hline
\end{tabular}

The $f$-ratio value is 528.73271. The $p$-value is $<0.00001$. The result is significant at $p<0.05$.

The results of the Anova test showed that there is a significant difference in points of view between guests and practitioners as revealed in Table 6. Table 7 displays Anova test results between academics and guests.

Table 7. Anova Test Results between Academics and Guests

\begin{tabular}{|l|c|c|c|}
\hline \multicolumn{4}{|c|}{ Summary of Academics and Guests Data } \\
\hline & \multicolumn{3}{|c|}{ Treatments } \\
\cline { 2 - 4 } & 1 & 2 & Total \\
\hline $\mathrm{N}$ & 10 & 10 & 20 \\
\hline$\sum \mathrm{X}$ & 180 & 1963.8 & 2143.8 \\
\hline Mean & 18 & 196.38 & 107.19 \\
\hline$\sum \mathrm{X}^{2}$ & 3398 & 390874.52 & 394272.52 \\
\hline Std.Dev. & 4.1899 & 24.0912 & 93.0418 \\
\hline
\end{tabular}

\begin{tabular}{|l|c|c|c|l|}
\hline \multicolumn{5}{|c|}{ ANOVA of Academics and Guests } \\
\hline Source & SS & df & MS & \\
\hline $\begin{array}{l}\text { Between- } \\
\text { treatments }\end{array}$ & 159097.122 & 1 & 159097.122 & $F=532.14921$ \\
\hline Within-treatments & 5381.476 & 18 & 298.9709 & \\
\hline Total & 164478.598 & 19 & & \\
\hline
\end{tabular}

The $f$-ratio value is 532.14921. The $p$-value is $<0.00001$. The result is significant at $p<0.05$.

The results of the Anova test showed that there is a significant difference in points of view of guests and practitioners meaning that guests favor the idea while academics are conservative towards it. Table 8 displays Anova test results among groups of practitioners, academics, and guests. 
Table 8. Anova Test Results among Groups of Practitioners, Academics, and Guests

\begin{tabular}{|c|c|c|c|c|}
\hline \multicolumn{5}{|c|}{ Summary of Academics \& Practitioners and Guests' Data } \\
\hline & \multicolumn{4}{|c|}{ Treatments } \\
\hline & 1 & 2 & 3 & Total \\
\hline $\mathrm{N}$ & 10 & 10 & 10 & 30 \\
\hline$\sum \mathrm{X}$ & 200 & 180 & 1963.8 & 2343.8 \\
\hline Mean & 20 & 18 & 196.38 & 78.127 \\
\hline$\sum \mathrm{X}^{2}$ & 4072 & 3398 & 390874.5 & 398345 \\
\hline Std.Dev. & 2.8284 & 4.1899 & 24.0912 & 86.1497 \\
\hline
\end{tabular}

\begin{tabular}{|l|c|c|c|c|}
\hline \multicolumn{5}{|c|}{ ANOVA of Academics \& Practitioners and Guests' Data } \\
\hline Source & SS & df & MS & \\
\hline Between-treatments & 209778 & 2 & 104888.9 & $F=519.30178$ \\
\hline Within-treatments & 5453.48 & 27 & 201.9806 & \\
\hline Total & 215231 & 29 & & \\
\hline
\end{tabular}

The $f$-ratio value is 519.30178. The $p$-value is $<0.00001$. The result is significant at $p<0.05$.

The results of the Anova test showed that there is a significant difference in points of view of guests as compared to practitioners and academics. It is obvious that academics are more conservative towards the use of private dwellings in Old Historic Cairo as Airbnb rent listings while practitioners and guests favor and support the idea.

In conclusion, it can be observed that guests were the most interested group in the use of homes in the area and were very enthusiastic about that while practitioners and academics were less enthusiastic and more pragmatic and focused on the benefits of the application of the idea. It might also be noted that academics were the least enthusiastic group among all groups. The two main groups, i.e., practitioners and academics at one side and guests on the other sidemay look different in views, however, from another perspective the authors see that the two views complement each other. In other words, practitioners need to adopt guests' views and priorities regarding the application of the idea aforementioned to be able to achieve their desired general scope benefits. A demand-driven approach is needed from the side of practitioners and academics to cope up with the priorities of guests and be able to realize the return on investments devoted to the preservation, restoration, and upgrade of Old Historic Cairo.

\section{Conclusions and Recommendations}

From the previous analysis, it can be concluded that all of (guests, professional practitioners, MoT, and ETF high-rank officials and academics) all agreed on the value-added of using private homes in the Old Cairo historic area as Airbnb rent listings. There were some differences among them, but these differences refer only to the level of enthusiasm they show towards the idea. All 
parties concerned assured the socio-economic positive impact of the idea for Old Cairo historic area and its residents, meanwhile, guests showed their welling and desire to stay in these homes. It is therefore recommended that MoT creates a classification for these homes to fit into and to permit these homes to use Airbnb under this updated classification, also ETF: to launch awareness programs for residents of the area. Academics are required to include this area in heritage programs. Many high-rank officials from other governmental entities are required to show cooperation towards the application of this idea.

\section{References}

Airbnb (2017) Airbnb 2017 summer travel report. Retrieved from: https://news.airbnb. com/airbnb-2017-summer-travel-trends/. [Accessed 11 November 2020]

Botsman R (2010) the case for collaborative consumption. Speech Presented at TED x Sydney, Sydney. Retrieved from: https://www.ted.com/talks/rachel_botsman_the_ca se_for_collaborative_consumption [Accessed 28 April 2017]

Botsman R, Rogers R (2010) what's mine is yours: the rise of collaborative consumption. New York, NY, USA: Harper Collins E-Books.

Bridges J, Vásquez C (2018) If nearly all Airbnb reviews are positive, does that make them meaningless? Current Issues in Tourism 21(18): 2057-2075.

Cardaci V, Cecchini G, Malleo F, Pagano M, Virruso S (n.d.) Tourism integrated relational and environmentally sustainable in the Mediterranean: a utopia or a necessary strategy for development. Retrieved from: https://iris.unipa.it/handle/104 47/46766\#. X6u0Q2j0nIU. [Accessed 11 November 2020]

Chen C, Rothschild R (2010) an application of hedonic pricing analysis to the case of hotel rooms in Taipei. Tourism Economics 16(3): 685-694.

Chica-Olmo J, González-Morales JG, Zafra-Gómez JL (2017) Effects of location on Airbnb apartment pricing in Málaga. Tourism Management 77(Apr): 103981.

Egypt Today (2019) For $1^{\text {st }}$ time since 2006, Egypt updates hospitality criteria. Retrieved from: https://www.egypttoday.com/Article/6/74619/For-1st-time-since-2006-Egyptupdates-Hospitality-Criteria. [Accessed 11 November 2020]

Egyptian Tourism Federation (ETF) (2018) ETF report, 2018. Cairo, Egypt: ETF Publications.

Ert E, Fleischer A, Magen N (2016) Trust and reputation in the sharing economy: the role of personal photos in Airbnb. Tour Management 55(Aug): 62-73.

Fierro A, Salmón C (2017) El impacto del turismo en el casco viejo de Bilbao mediante los modelos de economía colaborativa: una aproximación a través de una distribución binomial negativa. (The impact of tourism in the old quarter of Bilbao through collaborative economy models: an approach through a negative binomial distribution). Lurralde: Investigación y Espacio 41: 175-201

Fletcher-Jones N (2016) The lost city of Ibn Tulun. Retrieved from: https://bit.ly/32y1Qzp. [Accessed 11 November 2020]

Guttentag D (2015) Airbnb: disruptive innovation and the rise of an informal tourism accommodation sector. Current Issues in Tourism 18(12): 1192-1217.

Hamari J, Sjöklint M, Ukkonen A (2016) the sharing economy: why people participate in collaborative consumption. Journal of the Association of Information Science and Technology 67(9): 2047-2059.

Hu N, Zhang J, Pavlou PA (2019) Overcoming the J-shaped distribution of product reviews. Communications of the ACM 52(10) 144-147. 
Huurne M, Ronteltap R, Corten R, Buskens V (2017) Antecedents of trust in the sharing economy: a systematic review. Journal of Consumer Behavior 16(6): 485-498.

Kolar T, Zabkar VA (2010) Consumer-based model of authenticity: An oxymoron or the foundation of cultural heritage marketing? Tourism Management 31(5): 652-664.

Lalicic L, Weismayer C (2017) the role of authenticity in Airbnb experiences. In Information and Communication Technologies in Tourism. Berlin/Heidelberg, Germany: Springer.

Lee S, Kim DY (2018) the brand personality of Airbnb: application of user involvement and gender differences. Journal of Travel Tourism and Marketing 35(1): 32-45.

Liang LJ, Choi HC, Joppe M (2018) Exploring the relationship between satisfaction, trust, and switching intention, repurchase intention in the context of Airbnb. International Journal of Hospitality Management 69(Jan): 41-48.

Lieber A, Gibson HS, Temperly W, Peedell S, Poyart E, Hancher M et al. (2015), A global map of travel time to cities to assess inequalities in accessibility in 2015. Nature 533(7688): 333-336.

Mashat R (2018) New hospitality criteria (hotel classification criteria) for Egyptian hotels symposium, Egypt. Retrieved from: https://egyptindependent.com/tourism-ministryannounces-new-hospitality-criteria-for-egypts-hotels/. [Accessed 11 November 2020]

Mody M, Suess C, Lehto X (2019) The accommodation experiencescape: a comparative assessment of hotels and Airbnb. International Journal of Contemporary Hospitality Management 29(9): 2377-2404.

Official Norwegian Report (NOU) (2017) The sharing economy. The Spanish National Commission on Markets and Competition. Retrieved from: https://delingsokonomi. dep.no/files/2015/11/NOU_2017-4_chapter_1.pdf. [Accessed 11 November 2020]

Pallant J (2007) a step by step guide to data analysis using SPSS. SPSS Survival Manual. Berkshire UK: McGraw-Hill Education.

Pappas N (2019) the complexity of consumer experience formulation in the sharing economy. International Journal of Hospitality Management 77(Jan): 415-424.

Parigi P, Cook K (2015) Trust erodes over time in the online world, Stanford experts say. Retrieved from: https://news.stanford.edu/pr/2015/pr-sharing-trust-online-031815.ht ml. [Accessed 6 November 2020]

Schor JB, Fitzmaurice CJ (2015). Collaborating and connecting: the emergence of the sharing economy. In Handbook of Research on Sustainable Consumption. Dortmund, UK: Edward Elgar Publishing.

Schor JB, Lee CW, Parigi P, Cook KS, Walker ET (2015) On the sharing economy. Contexts 14(1): 12-19.

Sigala M (2017) Collaborative commerce in tourism: implications for research and industry. Current Issues in Tourism 20(4): 346-347.

So KKF, Oh H, Min S (2018) Motivations, and constraints of Airbnb consumers: Findings from a mixed-methods approach. Tourism Management 67(Aug): 224-242.

Sthapit E (2013) Tourist Expectations of memorable experiences: testing the memorable tourism experience scale (MTEs) among tourists to Rovaniemi. Lapland, Finland: University of Lapland.

Sthapit E, Barreto JJ (2018) sharing in the host-guest relationship: perspectives on the Airbnb hospitality experience. Anatolia 29(2): 282-284.

Sthapit E, Björk P (2019) Sources of distrust: Airbnb guest's perspective. Tourism Management Perspectives 31(Jul): 245-253.

Sun N, Liu D, Zhu A, Chen Y, Yuan Y (2019) Do Airbnb's super hosts deserve the badge? An empirical study from China. Asia Pacific Journal of Tourism Research 24(4) 296-313. 
Swelim T (2015) Ibn Tulun: his lost city and great mosque. Cairo: The American University in Cairo Press.

Tussyadiah L (2015) an exploratory on drivers and deterrents of collaborative consumption in travel. In L Tussyadiah, A Inversini (eds.), Information \& Communication Technologies in Tourism, 178-179.

Tussyadiah L, Pesonen J (2018) Impacts of peer to peer accommodation use on travel patterns. Journal of Travel Research 55(8): 1022-1040.

Wu J, Zeng M., Xie KL (2017) Chinese travelers' behavioral intentions toward roomsharing platforms: the influence of motivations, perceived trust, and experience. International Journal of Contemporary Hospitality Management 29(10): 2688-2707.

Zervas G, Proserpio D, Byers J (2015a) The rise of the sharing economy: estimating the impact of Airbnb on the hotel industry. Journal of Marketing Research 54(5): 687705 .

Zervas G, Proserpio D, Byers J (2015b) The first look at online reputation on Airbnb, where every stay is above average. Retrieved from: https://papers.ssrn.com/sol3/pa pers.cfm?abstract_id=2554500. [Accessed 15 October 2018]

Zervas G, Proserpio D, Byers JW (2017) Economy based accommodation rental: a study of listings from 33 cities on Airbnb.com. International Journal of Hospitality Management 62(Apr): 120-131.

Zhang Z, Chen RJC, Han LD, Yang L (2018) Key factors affecting the price of Airbnb listings: a geographically weighted approach. Sustainability 9(9): 1635. 
